\title{
GEOLOGI GUNUNGAPI PURBA SOREANG DAN IMPLIKASINYA TERHADAP POTENSI CEBAKAN EMAS
}

\section{GEOLOGY OF SOREANG ANCIENT VOLCANO AND ITS IMPLICATIONS FOR GOLD DEPOSITS POTENTIAL}

\author{
Rinaldi Ikhram ${ }^{1^{*}}$, Irfan Arifin ${ }^{2}$, R. Irvan Sophian ${ }^{3}$ \\ IInstitut T eknologi Sumatera; Lampung Selatan \\ ${ }^{2}$ U BPE Pongkor PT. Aneka Tambang; Jakarta \\ ${ }^{3} U$ niversitas Padjadjaran, Bandung/Sumedang
}

Received: 2021, M ay $10^{\text {th }}$

A ccepted: 2021, July $2^{\text {nd }}$

\section{Keyword: \\ Ancient volcano; \\ Geomophology; \\ Gold Deposits; \\ Soreang; \\ Volcanic Facies.}

\section{Corespondent Email: \\ rinaldi.ikhram@gl.itera.ac.id}

\section{H ow to cite this article:}

Ikhram, R., A rifin, I., \& Sophian, R.I. (2021). Geologi Gunungapi Purba Soreang dan I mplikasinya Terhadap Potensi Cebakan Emas. Jurnal Geofisika Eksplorasi, 7(2), 111-125.

\begin{abstract}
Abstrak. Gunungapi Purba Soreang yang terletak di Kabupaten Bandung merupakan gunungapi yang tidak aktif dan tererosi kuat. Daerah ini memperlihatkan susunan litologi gunungapi strato-vulanik serta memiliki morfologi perbukitan bergelombang tak beraturan dan bukit-bukit soliter. Penelitian ini dilaksanakan untuk mengetahui hubungan geomorfologi dan geologi Gunungapi Purba Soreang dengan potensi keberadaan cebakan emas. Metode yang dilakukan adalah analisis geomorfologi, pemetaan vulkanostratigrafi dan analisis struktur geologi serta identifikasi zona alterasi dan mineralisasi. Berdasarkan peta morfografi dan kemiringan lereng, daerah penelitian menunjukan bentuk bentang alam khas gunungapi berupa bentuk yang menyerupai lingkaran atau circular feature yang dihasilkan oleh batuan intrusi, kubah lava, dan leher gunungapi purba, sebagai petunjuk lokasi sumber erupsi. Produk gunungapi purba Soreang memperlihatkan fasies sentral hingga distal dalam beberapa satuan gumuk dan khuluk. Litologi penyusun daerah ini di antaranya intrusi andesit dan diorit yang sebagian besar telah mengalami alterasi hidrotermal, perselingan lava dan breksi piroklastika dan tuff. Litologi ini menunjukkan bahwa Gunungapi Soreang merupakan jenis strato-vulanik. Di area Gunungapi Purba Soreang ini telah dilakukam eksplorasi potensi mineralisasi emas pada zona sentral. Pertambangan tradisional juga telah dilakukan oleh masyarakat lokal. Berdasarkan analisis terpadu bentang alam dengan litologi, perkiraan tubuh Gunungapi Purba Soreang dan zona sentral gunungapi tersebut dapat diidentifikasi. Hasil identifikasi tersebut digunakan untuk membantu penetapan area eksplorasi potensi cebakan emas di wilayah Soreang.
\end{abstract}

Abstract. Soreang Ancient Volcano, located in Bandung Regency, is an inactive 
C) 2021 JGE (Jurnal Geofisika Eksplorasi). This article is an openaccess article distributed under the terms and conditions of the Creative Commons Attribution (CC BY NC) and strongly eroded volcano. This area shows the lithological arrangement of stratovolcano and has irregular wavy hills and solitary hills morphology. This research was conducted to determine the relationship between the geomorphological and geological of the Soreang Ancient Volcano with the potential of gold deposits. This research uses several methods including geomorphological analysis, volcanostratigraphic mapping and geological structure analysis as well as identification of alteration and mineralization zones. Based on the morphography and slope classes map, the research area shows the typical volcanic landscape in the form of circular features produced by intrusive rocks, lava domes, and ancient volcanic necks, indicating the location of the eruption source. The ancient volcanic products of Soreang show central to distal facies in several volcanic units. The lithology of this area includes andesite and diorite intrusion, most of which have undergone hydrothermal alteration, alternating lava and pyroclastic and tuff breccias. This lithology shows that Soreang Volcano is a type of stratovolcano. In the Soreang A ncient V olcano area, several gold explorations have been conducted in the central zone. The local people have also conducted traditional mining there. Based on an integrated analysis of the geomorphology with lithology, the estimated body of the Ancient Soreang Volcano and the central zone of the volcano can be mapped. The indentification results are used to help determine the exploration area for potential gold deposits in the Soreang area.

\section{PENDAHULUAN}

Aktivitas vulkanisme di Indonesia telah berlangsung sejak masa lampau hingga saat ini yang mengasilkan rangkaian busur gunungapi aktif mapun yang telah mati. Hal tersebut berkaitan dengan sejarah subduksi Indonesia terutama Indonesia bagian barat yang telah berlangsung sejak Kapur Akhir (Martodjojo, 2003) atau sekitar 76 juta tahun yang lalu (N gkoimani, 2005) hingga masa kini. Aktivitas vulkanisme ini telah diketahui berpotensi membawa mineralisasi logam sulfida terutama emas. Sebagian besar pertambangan emas dan logam sulfida di Indonesia berasosiasi dengan aktivitas vulkanisme. Penelitian mengenai karakteristik gunungapi sangatlah penting dalam strategi eksplorasi emas dan logam sulfida lainnya untuk memperoleh potensi cadangan-cadangan terbaru di wilayah Indonesia (Bronto, 2006). Penelitian ini dilaksanakan untuk mengetahui hubungan geomorfologi dan geologi Gunungapi Purba
Soreang dengan potensi keberadaan cebakan emas.

Aktivitas vulkanisme di Indonesia telah berlangsung sejak masa lampau hingga saat ini yang mengasilkan rangkaian busur gunungapi aktif mapun yang telah mati. Hal tersebut berkaitan dengan sejarah subduksi Indonesia terutama Indonesia bagian barat yang telah berlangsung sejak Kapur Akhir (Martodjojo, 2003) atau sekitar 76 juta tahun yang lalu (N gkoimani, 2005) hingga masa kini. Aktivitas vulkanisme ini telah diketahui berpotensi membawa mineralisasi logam sulfida terutama emas. Sebagian besar pertambangan emas dan logam sulfida di Indonesia berasosiasi dengan aktivitas vulkanisme. Penelitian mengenai karakteristik gunungapi sangatlah penting dalam strategi eksplorasi emas dan logam sulfida lainnya untuk memperoleh potensi cadangan-cadangan terbaru di wilayah Indonesia (Bronto, 2006). Penelitian ini dilaksanakan untuk mengetahui hubungan geomorfologi dan geologi Gunungapi Purba 
Soreang dengan potensi keberadaan cebakan emas.

Daerah penelitian terletak di daerah Kecamatan Soreang hingga Kecamatan Cililin dan sekitarnya yang termasuk dalam kawasan Pegunungan Bandung Selatan (Gambar 1). Daerah penelitian disebut sebagai gunungapi purba yang dinamakan Gunungapi Saguling (Bronto, 2003; Bronto, dkk., 2004). Pada penelitian selanjutnya mengenai Stratigrafi Gunungapi Daerah Bandung Selatan, satuan batuan penyusun daerah ini sebagai Satuan Batuan Gunungapi Soreang (Bronto, dkk., 2006). Penamaan gunungapi purba tersebut memang dapat berbeda-beda karena menyangkut dengan aspek geografi, namun dapat dipastikan bahwa semua aspek geologi di daerah ini menunjukan keberadaan suatu gunungapi purba yang telah aktif berjuta tahun yang lalu.

Kondisi geologi daerah penelitian diketahui memiliki sumber daya geologi baik logam maupun non-logam. Penambangan bahan galian industri non logam seperti tambang andesit dan mineral lempung banyak dijumpai di sini. Selain itu, daerah ini memiliki potensi kandungan emas dan logam sulfida. Pertambangan emas telah dibuka oleh warga masyarakat sekitar Desa Kutawaringin, Kecamatan Soreang. Beberapa perusahaan seperti PT. Aneka Tambang Tbk dan PT. Pancaraksa Abadi telah melaksanakan eksplorasi di area ini dan menemukan beberapa bukti potensi keberadaan kandungan emas (Bronto, 2006). Potensi mineralisasi emas dan logam sulfida lain diduga kuat erat kaitannya dengan aktivitas vulkanisme Gunungapi Purba Soreang. Maka dari itu, pemahaman mengenai tubuh gunungapi beserta penentuan fasiesnya akan sangat bermanfaat bagi strategi eksplorasi emas di kemudian hari.

Dalam menginterpretasi gambaran bentuk tubuh gunung dan fasiesnya, beberapa pendekatan metode perlu dilaksanakan
(Bronto dkk., 2006). Penelitian ini menggunakan pendekatan analisis data yang meliputi, penginderaan jauh dan geomorfologi, lalu di kombinasikan dengan data lapangan berupa data persebaran litologi, stratigrafi batuan gunungapi, bukti vulkanologi fisik, struktur geologi, dan analisis petrologi. A kan tetapi, data geokimia batuan belum diperoleh.

\section{TINJAUAN PUSTAKA}

Berdasarkan letaknya, secara fisiografi daerah penelitian termasuk kedalam Zona Bandung (Van Bemmelen, 1949). Zona Bandung merupakan daerah gunungapi yang merupakan suatu depresi jika dibanding dengan Zona Bogor dan Zona Pegunungan Selatan. Selain itu, zona ini mengalami perlipatan pada Zaman Tersier. Zona Bandung sebagian besar terisi oleh endapan vulkanik muda produk dari gunungapi disekitarnya dan juga dikelilingi oleh gunungapi aktif dan deretan perbukitan sisa gunungapi purba, salah satunya adalah daerah penelitian itu sendiri.

Berdasarkan Peta Geologi Lembar Bandung (Silitonga, 1973) dan Lembar Garut (Alzwar, dkk., 1992) stratigrafi regional daerah penelitian dapat diketahui. Satuan batuan tertua adalah Formasi Beser dan batuan terobosan. Formasi Beser (Tmb) tersebar di pojok barat laut peta lembar Garut, di daerah Soreang, dan di wilayah Kecamatan Arjasari, Baleendah, dan Ciparay di sebelah timur kota Banjaran. Satuan batuan ini berupa batuan gunungapi yang terdiri atas breksi tufan dan lava bersusunan andesit basal. Bersama-sama dengan batuan terobosan, kelompok batuan gunungapi ini menyebar ke utara (peta geologi lembar Bandung, Silitonga, 1973) dan ke barat laut (peta geologi lembar Cianjur; Sudjatmiko, 1972). Keduanya tidak menyebutkan sebagai Formasi Beser, tetapi hanya menyatakan sebagai breksi tufan, lava, batupasir, dan konglomerat $(\mathrm{Pb})$. Sekalipun memperkirakan Formasi Beser di sini berumur M iosen Akhir, 
Sujatmiko (1972) dan Silitonga (1973) memberikan umur Pliosen.

Batuan terobosan tersebar hingga ke sebelah selatan Cimahi dan tenggara Waduk Saguling (Silitonga, 1973; Sudjatmiko, 1972). Satuan batuan ini bersusunan andesit, basal, dan dasit. Analisis K-Ar terhadap batuan ini di Selacau dan Paseban, masing-masing memberikan umur 4,08 juta tahun dan 4,07 juta tahun (Sunardi \& Koesoemadinata, 1999). Penelitian fasies gunungapi dapat dimanfaatkan untuk pencarian sumber baru mineralisasi logam sulfida berdasarkan konsep pusat erupsi gunungapi sebagai strategi untuk penelitian emas (Bronto, 2003; Bronto, dkk., 2003). Interaksi antara gas asam, larutan logam, dan panas dari magma dengan air onduit di dalam onduit gunungapi membentuk fluida hidrotermal yang pada akhirnya menghasilkan batuan ubahan dan mineralisasi. Konduit atau istilah lain diatrema, vent, dan korok gunungapi terletak di bawah kawah dan di atas dapur magma. Ini berarti bahwa endapan mineralisasi cenderung lebih intensif pada zona fasies pusat gunungapi. Oleh sebab itu, dalam rangka pencarian sumber baru mineralisasi maka sebagai langkah pertama adalah dengan mencari fasies pusat gunungapi purba.

Berdasarkan sumber erupsinya, batuan gunungapi di daerah Bandung Selatan dapat dibagi menjadi sembilan satuan batuan gunungapi yaitu: (1) Satuan Batuan Gunungapi Soreang (SV), (2) Satuan Batuan Gunungapi Baleendah (BV), (3) Satuan Batuan Gunungapi Pangalengan (PV), (4) Satuan Batuan Gunungapi Tanjaknangsi (TV), (5) Satuan Batuan Gunungapi Kuda (KV), (6) Satuan Batuan Gunungapi Kendang (KdV), (7) Satuan Batuan Gunungapi Dogdog (DV), (8) Satuan Batuan Gunungapi Wayang-Windu (WV), dan (9) Satuan Batuan Gunungapi Malabar (MV) (Gambar 2) (Bronto \& $\mathrm{H}$ artono, 2006).

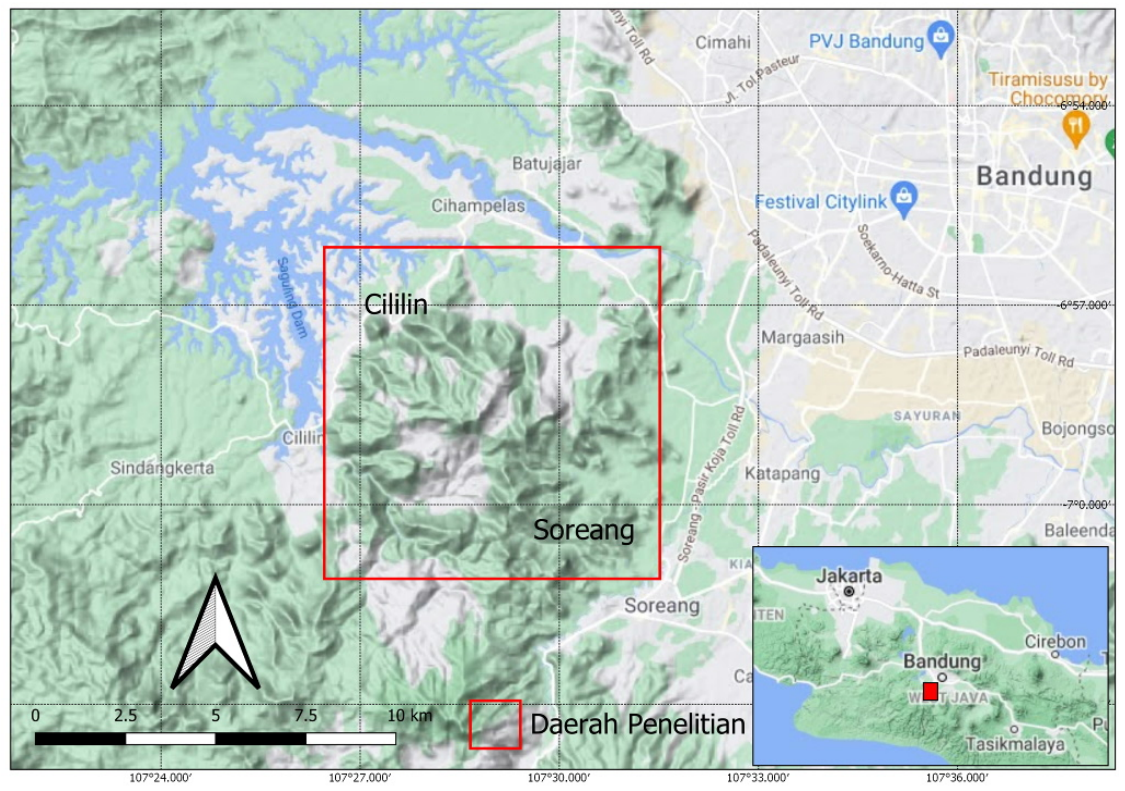

Gambar 1. Lokasi daerah penelitian terletak di Kecamatan Cililin dan Soreang, Kabupaten Bandung, \pm 1 jam dari Kota Bandung, Jawa Barat. 


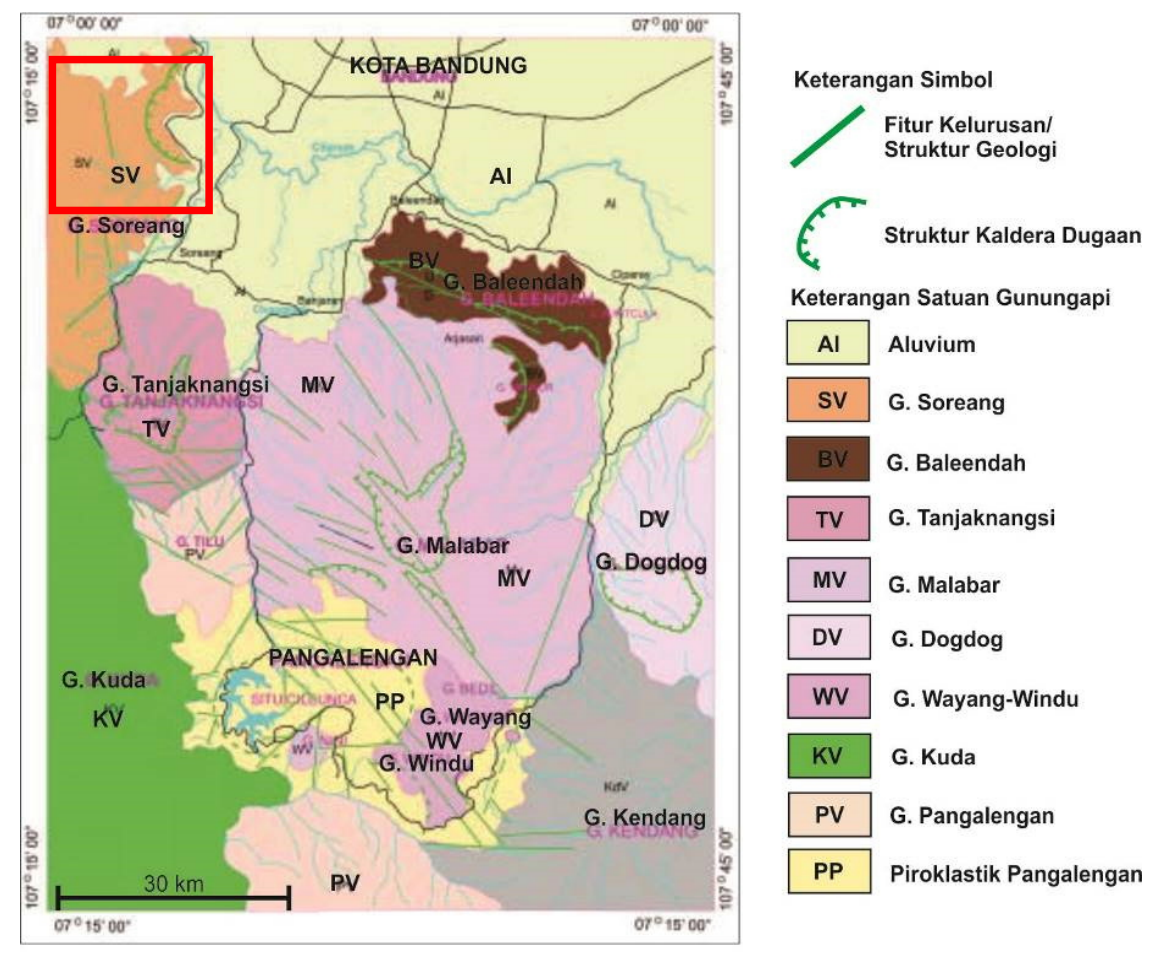

Gambar 2. Peta Geologi Gunungapi daerah Bandung Selatan (modifikasi oleh Silitonga, 1973). Kotak merah merupakan cakupan daerah penelitian.

Daerah penelitian termasuk dalam Satuan Batuan Gunungapi Soreang. Satuan batuan ini tersebar di bagian barat laut daerah penelitian, atau di barat laut kota Soreang yang merupakan ibu kota Kabupaten Bandung. Dari citra Landsat kawasan Gunung Soreang berbentuk membulat, sehingga puncaknya dinamakan Gunung Buleud, dan mempunyai relief paling kasar dibandingkan dengan kawasan gunungapi yang lain. Di bagian tengah terdapat morfologi cekungan melingkar yang diperkirakan sebagai fasies sentral gunungapi purba tersebut. Batuan pada fasies proksimal membentuk punggungan perbukitan yang melandai ke arah fasies medial, tetapi berlereng curam menuju fasies sentral Agak terpisah di tepi timur laut terdapat tinggian yang juga mempunyai bentuk bukaan ke arah timur menghadap ke Dataran Bandung. Bentuk tinggian dan bukaan tersebut diperkirakan sebagai kerucut gunungapi kedua di dalam kawasan Gunung Soreang. Kemunculan gunungapi tersebut tidak lepas dari pengaruh kegiatan tektonika dan pensesaran di daerah Bandung Selatan.

\section{METODE PENELITIAN}

Metode penelitian melitupi studi literatur berdasarkan Peta Geologi Regional, publikasi dan laporan dari peneliti terdahulu. Identifikasi geomorfologi yang meliputi analisis citra DEM (Grosse, dkk., 2012; Prima \& Yoshida, 2010), morfografi, morfometri dan morfogenetik. Analisis morfografi dilakukan dengan mengolah data peta topografi, pola aliran sungai. Peta morfometri merupakan peta klasifikasi kemiringan lereng menurut klasifikasi ITC (Van Zuidam, 1977) untuk membagi kontur berdasarkan warna masing kelompok kemiringan lereng, kemudian didijitasi kembali untuk dapat dikombinasi manjadi sebuah peta tematik morfometri daerah penelitian.

Cakupan penelitian ini adalah area seluas $100 \mathrm{~km}^{2}$ di daerah Kecamatan Cililin hingga Kecamatan Soreang dan sekitarnya pada skala 
peta 1:25000. Data yang diperoleh diantaranya adalah persebaran dan karakteristik litologi, stratigrafi gunungapi, dan bukti-bukti struktur geologi. Karakteristik litologi lalu diperkuat dengan analisis sayatan batuan melalui petrografi di bawah mikroskop.

\section{HASIL DAN PEMBAHASAN}

\subsection{Geomorfologi Gunungapi Purba Soreang}

Pada umunya Gunungapi Purba Soreang memiliki relief perbukitan tinggi, dan perbukitan kerucut, pola punggungan tidak teratur dengan lembahan-lembahan yang berbentuk $U$ tajam hingga $V$ tajam dan terdapat relief pedataran.

Dalam mengelompokkan pola aliran sungai, digunakan metode perbandingan pola aliran (drainage pattern) dengan klasifikasi pola umum berdasarkan hubungan antar aliran, arah aliran, dan pola bentuk (Fryirs \& Brierley, 2012). Pola pengaliran di daerah penelitian berjenis Radial, Subparallel, subtrellis, dan Rektangular. Pola aliran radial (Tanda "A" pada Gambar 3) terdapat pada topografi kubah, seperti kerucut vulkanik atau topografi lain dengan bentuk mengerucut yang terisolasi (Huggett, 2007). Dengan terminologi tersebut diinterpretasikan bahwa daerah dengan pola aliran ini memiliki topografi kubah atau kerucut vulkanik seperti intrusi batuan beku atau volcanic neck. M orfologi ini juga dapat dikontrol oleh bentukan kaldera purba.

Pola aliran subparallel, subtrellis dan rektangular pada daerah peneltian menunjukan adanya kontrol struktur geologi berupa lipatan, sesar dan kekar.

Analisis citra DEM khususnya pada pengelompokan kelas kemiringan lereng menunjukkan fitur geomorfologi Gunungapi Purba Soreang. Kemiringan lereng daerah pemetaan menjadi: Kemiringan lereng datar, agak landai, landai, agak curam, hingga curam (Gambar 4).

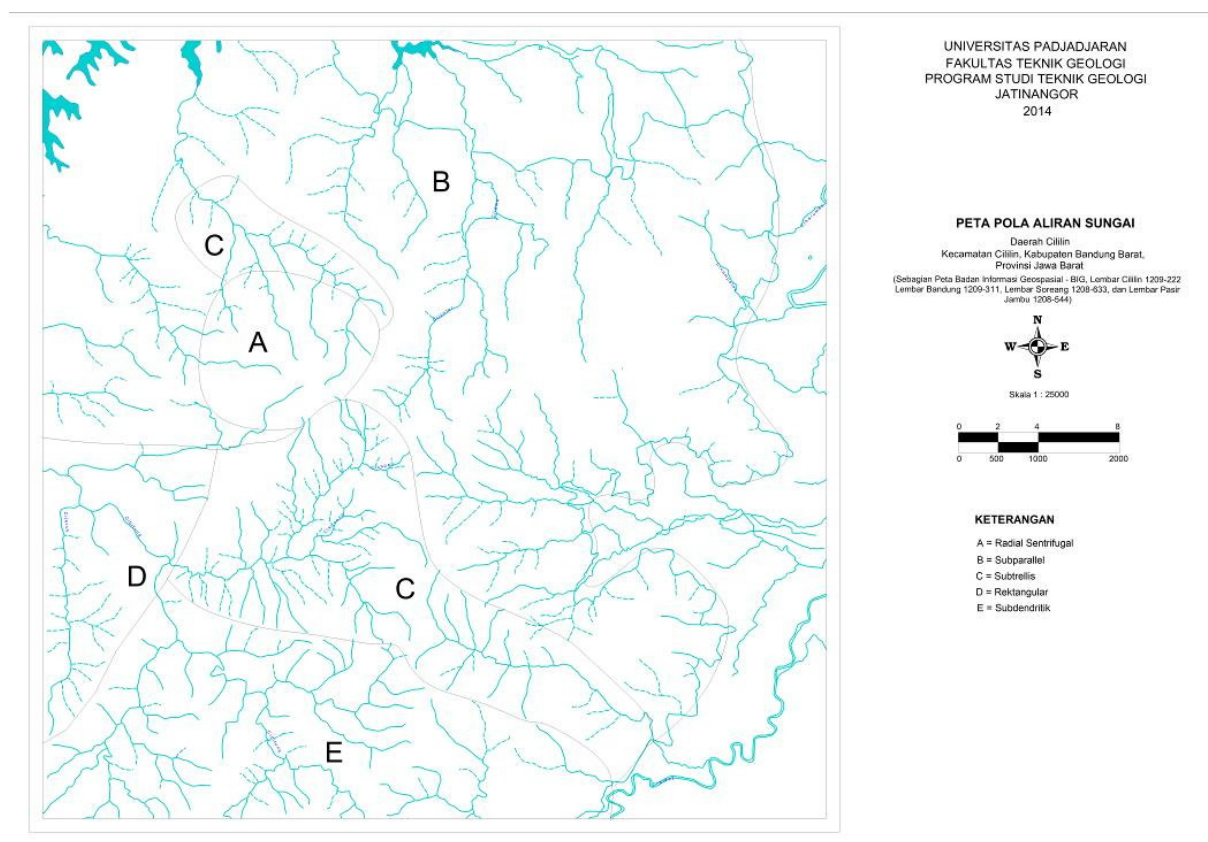

Gambar 3. Pola Pengaliran Sungai 


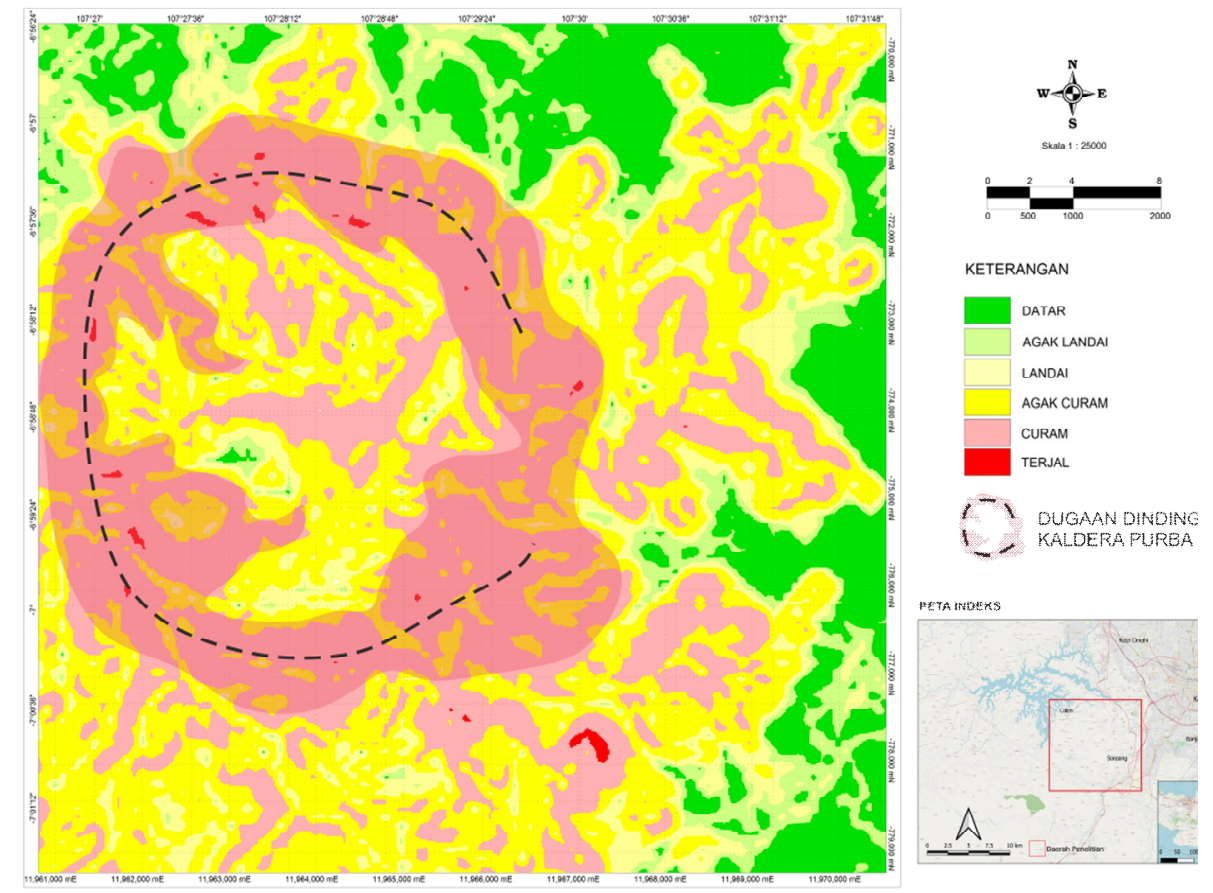

Gambar 4. Peta Kelerengan berdasarkan Klasifikasi ITC (V an Zuidam, 1977)

Berdasarkan pembagian kemiringan tersebut dapat diinterpretasikan beberapa fenomena geologi yang terjadi di daerah penelitian. Daerah yang diberi warna hijau sampai kuning muda adalah daerah yang memiliki kemiringan lereng $0-8^{\circ}$ dan dikelompokkan menjadi kemiringan lereng datar hingga landai. Daerah dengan kemiringan lereng seperti ini dapat diduga tersusun oleh batuan yang tidak resisten terhadap erosi, sehingga terkikis hingga datar, atau disebut denudasi. Biasanya terdapat pada bentangalam fluvial dimana proses erosi dan sedimentasi berlangsung dengan intensitas tinggi (Charlton, 2007). Dugaan lain adalah adanya struktur geologi yang menyebabkan perbedaan ketinggian yang signifikan pada masing-masing blok.

Daerah yang diberi warna kuning tua hingga merah muda adalah daerah yang memiliki kemiringan lereng $9^{\circ}-33^{\circ}$ dan dikelompokkan menjadi kemiringan lereng agak curam hingga curam. Daerah dengan kemiringan lereng seperti ini dapat diduga tersusun oleh batuan yang relatif resisten terhadap erosi. Dugaan sementara, daerah ini tersusun oleh batuan produk vulkanik yang kaya akan mineral-mineral resisten seperti batuan beku intrusi/ekstrusi dan piroklastik. Terlihat juga beberapa punggungan dengan kemiringan lereng curam memiliki pola kelurusan semacam gawir. Hal ini dapat diinterpretasikan disebabkan oleh pengaruh struktur geologi.

Jika diperhatikan daerah yang berwarna merah muda atau daerah dengan lereng curam pada peta morfometri menunjukkan pola melingkar/circular. Pola ini diduga merupakan bekas morfologi kaldera suatu gunungapi purba (Prima \& Yoshida, 2010). Dugaan ini diperkuat dengan melihat litologi yang menyusun pola ini yaitu batuan produk vulkanik.

Satuan geomorfologi pada daerah penelitian (Gambar 5) berdasarkan aspek, morfografi, morfogenetik morfometri, satuan geomorfologi pada daerah penelitian dibagi atas 5 satuan yaitu:

1. Satuan perbukitan intrusi curam

2. Satuan perbukitan vulkanik curam 
3. Satuan perbukitan sedimen struktural curam

4. Satuan perbukitan sedimen struktural agak curam

5. Satuan pedataran fluvial

Perbukitan Intrusi curam (ditunjukkan dengan warna merah pada Gambar 5) dipengaruhi proses endogen berupa intrusi hipabisal dari fasies sentral gunungapi purba yaitu berupa asosiasi batuan beku yang berupa kubah lava dan berbagai macam batuan terobosan semi gunungapi (subvolcanic intrusions) seperti halnya leher gunungapi (volcanic necks), sill, retas, dan kubah bawah permukaan (cryptodomes), dengan karakteristik batuan yang resisten terhadap erosi, sehingga membentuk suatu bukit kerucut soliter dan perbukitan memanjang.

Satuan Geomorfologi Perbukitan Vulkanik Curam (ditunjukkan dengan warna merah muda pada Gambar 5) terbentuk oleh proses endogen yang terjadi adalah aktivitas vulkanisme purba yang menghasilkan punggungan-lembahan memanjang dengan arah yang hampir terpencar dari suatu pusat gunungapi, tergerus dan terisi oleh material vulkanik, seperti aliran piroklastik dan lava.

Satuan Geomorfologi Perbukitan Struktural Curam dan Agak Curam (ditunjukkan dengan ungu tua dan ungu merah pada Gambar 5) terbentuk oleh proses endogen berupa aktivitas tektonik yang menghasilkan struktur geologi berupa kekar dan sesar, hal ini juga diindikasikan oleh pola aliran rektangular dan sub-dendritik.

Satuan Geomorfologi Pedataran Fluvial lebih dikontrol oleh proses eksogen, yaitu berupa pelapukan, erosi yang kuat dan pengendapan material-material lepas sehingga menghasilkan lereng yang datar.

Hasil analisis geomorfologi menunjukan bahwa dinding kaldera dan bagian lereng gunungapi purba Soreang meliputi daerah Patrol, Gn. Batu Keupeul, Pasir Panjang, Gn. Putri hingga Desa Mukapayung. Hasil ini berbeda dengan penelitian sebelumnya yang mengiterpretasikan bahwa pusat gunungapi purba berada di daerah CipendeuyKutawaringin dengan bukit-bukit disekitarnya seperti Gunung Buleud sebagai dinding kalderanya.

\subsection{Litologi dan Stratigrafi Gunungapi}

Ditinjau dari aspek satuan stratigrafi gunungapi, satuan ini dapat disebandingkan dengan Satuan Batuan Gunungapi Soreang menurut (Bronto, 2006). Umur keterbentukkan satuan gunungapi ini didasarkan pada hasil $\mathrm{K}-\mathrm{Ar}$ dating oleh (Sunardi \& Koesoemadinata, 1999) di Selacau dan Paseban yaitu Pliosen bawah sekitar 4.0 jtl. Interpretasi bentuk tubuh gunungapi dilakukan berdasarkan analisis geomorfologi (telah dibahas pada bab sebelumnya), adanya alterasi hidrotermal di zona pusat dimana litologi penyusunnya merupakan produk vulkanik primer, adanya pola penyebaran radier pada endapan-endapan vulkanik, tersingkapnya batuan beku plutonik yang disebut sub-vulkanik sebagai sisa magma yang membeku dalam dapur magma, intrusi ini juga memiliki asosiasi dengan batuan vulkanik yang menyebar disekitarnya. Satuan ini tersusun oleh batuan beku intrusi dan produk vulkanik yang dikelompokkan menjadi 3 buah gumuk sebagaimana penjelasan berikut (Gambar 6).

\subsubsection{Intrusi Diorit, Porfiri Andesit dan Porfiri Dasit}

Intrusi Porfiri Diorit ini secara megaskopis memperlihatkan sifat fisik warna segar abuabu, warna lapuk coklat keabuan, indeks warna mesokratik, tekstur porifiritik, kemas inequigranular, bentuk krital subhedral, bentuk mineral hipidiomorf, struktur masif (Gambar 7). Komposisi mineral yang terkandung diantaranya kuarsa plagioklas, hornblenda, piroksen, dan masa dasar mikroplagioklas. Pada intrusi dasit, terlihat kuarsa yang lebih melimpah. Mineral-mineral ubahan ditemukan di beberapa titik dalam 
jumlah yang melimpah. Diantaranya adalah kehadiran mineral hasil alterasi hidrothermal seperti chlorite yang merubah hornblenda, kalsit, dan mineral lempung dari ubahan plagioklas.

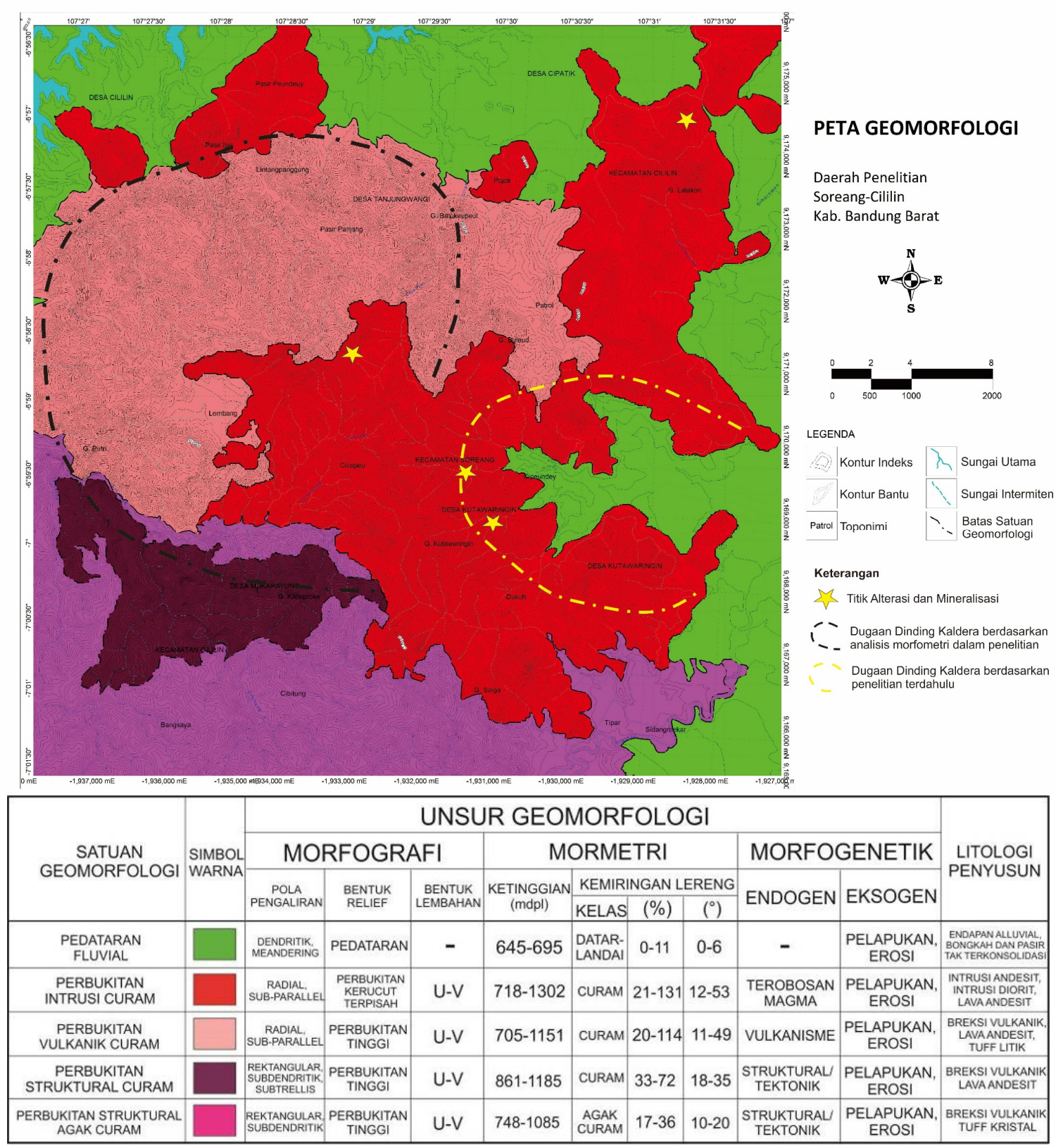

Gambar 5. Peta Geomorfologi Daerah Penelitian dan Pembagian Satuan Geomorfologi Berdasarkan Aspek M orfografi, M orfometri, dan M orfogenetik. 


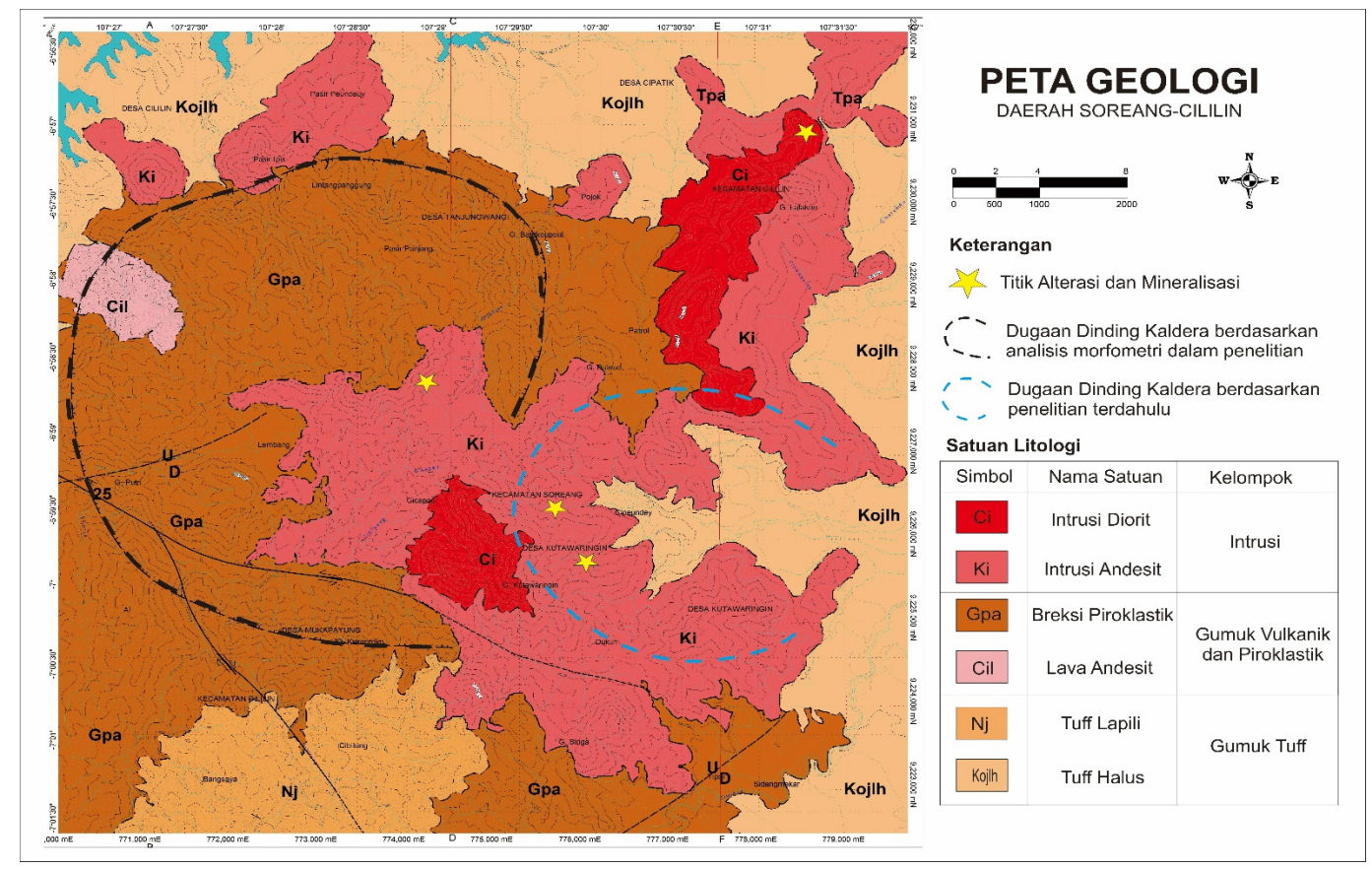

Gambar 6. Peta Geologi daerah penelitian dengan pembagian satuan litologi secara vulkanostratigrafi dan persebaran titik alterasi dan mineralisasi di daerah penelitian.

Satuan ini hadir dalam morfologi bukitbukit kerucut soliter, sebagian telah menjadi tambang galian $\mathrm{C}$ seperti di Desa Cipatik dan sekitarnya, juga pada bukit-bukit di Desa Kutawaringin. Satuan ini tersingkap baik pada lereng bukit yang terbuka oleh aktivitas tambang galian non-logam, lereng-lereng lembah satuan geomorfologi perbukitan intrusi curam, dan setempat ditemukan pada dasar sungai (Gambar 7).

Persebaran intrusi ini terpusat pada morfologi perbukitan intrusi curam yang dikelilingi morfologi perbukitan vulkanik melingkar yang diduga sebagai sisa kaldera purba. Pada beberapa bagian, persebaran intrusi dapat ditemukan pada bagian sisi gunungapi yang diduga sebagai sill atau dyke yang membentuk parasit. Pada bagian timur laut daerah penelitian, persebaran intrusi juga membentuk pola kelurusan timurlautbaratdaya yang diinterpretasikan muncul akibat kontrol sesar dengan arah yang sama.

\subsubsection{Gumuk Vulkanik dan Piroklastik}

Gumuk ini tersusun atas breksi aliran piroklastik dan aliran lava andesit. Breksi aliran piroklastik yang secara megaskopis memperlihatkan sifat fisik yaitu warna segar abu-abu kecoklatan, warna lapuk coklat kehitaman, breksi monomik, ukuran bongkahkerikil (diameter $5 \mathrm{~cm}-50 \mathrm{~cm}$ ), kemas terbuka, sortasi buruk, grain supported. Komponen breksi berupa andesit dengan karaktesistik warna lapuk coklat keabu-abuan, warna segar abu-abu kecoklatan, kemas inequgranular, tekstur porfo-afanitik. Kandungan mineral Kuarsa sebanyak 5-10\%, Plagioklas > 50\%, Alkali Feldspar 3-5\% mineral-mineral lain dan gelas vulkanik sebanyak 5-10\%. Komponen breksi vulkanik adalah jenis pofiri andesit, lava andesit, basalt dan porfiri diorit. Matriks berupa tuff dengan warna segar abu-abu keputih-putihan, warna lapuk abu-abu kecoklatan, ukuran tuff-lapili, permeabilitas baik, kandungan mineral feldspar, gelas, batuapung. Pada daerah baratdaya ditemukan beberapa singkapan breksi vulkanik matriks supported.

Terdapat pula lava andesit dengan sifat kenampakan ekstrusif, warna lapuk abu-abu kecoklatan, warna segar abu-abu gelap, indeks 

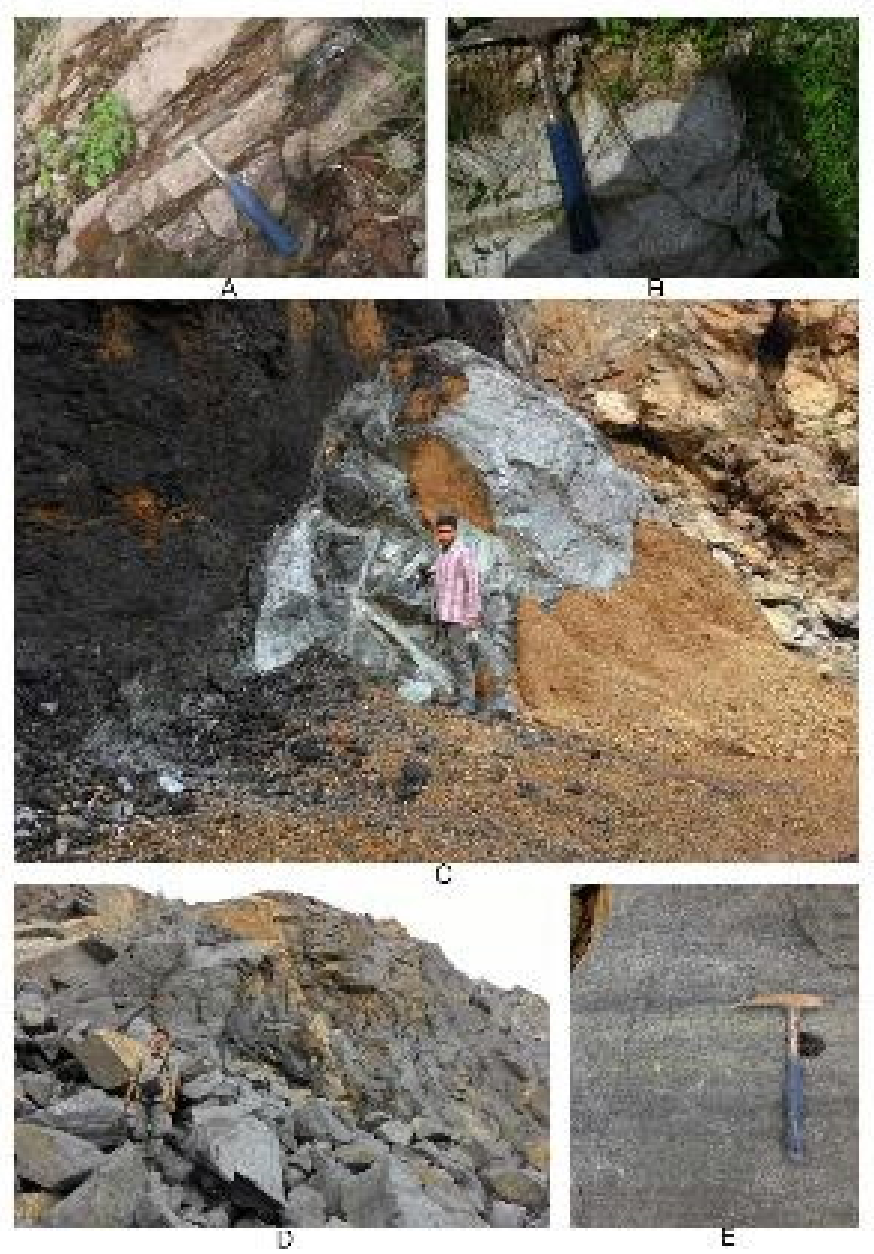

Gambar 7. (A) Foto dekat litologi penyusun Satuan Profiri Diorit (sheeting joint); (B) Foto dekat litologi penyusun Satuan Profiri Diorit; (C) Singkapan Porfiri diorit dan kontaknya dengan breksi vulkanik; (D) Singkapan intrusi porfiri diorit pada tambang galian; (E) Foto dekat Porfiri Diorit dengan struktur perlapisan akibat proses gravity settling.

warna mesokratik, kemas inequigranular, tekstur afanitik, bentuk kristal anhedral, allotriomorf, kristalisasi hipokristalin, setempat terlihat bertekstur vesikular halus. Komposisi mineral yaitu Kuarsa sebanyak $<5 \%$, Plagioklas sebanyak $\pm 50 \%$, Alkali Feldspar $<\%$, dan lain-lain (massa dasar, gelas, mineral mafic): $42 \%$. M ineral mafic yang melimpah adalah amfibol dan piroksen.

Di beberapa singkapan yang ditemui, terlihat adanya kontak yang tegas antara kedua jenis batuan diatas, yaitu breksi vulkanik dan lava andesit, dan juga memiliki arah kemiringan atau strike/dip. Strike/dip dalam hal ini bukan menunjukkan proses struktural pada tubuh batuan melainkan terbentuk akibat topografi pada saat aktivitas vulkanisme terjadi. Terdapat juga kontak erosional antar kedua jenis batuan. Dilihat dari arahnya menunjukkan pola radial yang diinterpretasikan sebagai arah persebaran produk vulkanik gunungapi purba Cililin. Di beberapa titik juga ditemukan breksi vulkanik ini membentuk morfologi seperti menara atau pipa-pipa tegak soliter. Diduga morfologi ini 
merupakan bagian pipa kerucut breksia (breccia pipe).

Satuan ini tersebar sekitar 20\% dari luas daerah penelitian daerah penelitian, hadir dalam morfologi bukit-bukit kerucut soliter, sebagian telah menjadi tambang galian C seperti di Desa Nanjung, Desa Cipatik dan sekitarnya, pada bukit-bukit di Desa Kutawaringin hingga ke Cicapeu dan Lembang di Kecamatan Cililin.

\subsubsection{Gumuk Piroklastik Tuff}

Di bagian baratdaya hingga tenggara tersusun oleh tuff kristal bewarna segar abuabu keputih-putihan, warna lapuk coklat muda keputih-putihan, besar butir tuff ash, bentuk butir subangular, pemilahan sedang, permeabilitas baik, kemas terbuka, kekerasan dapat diremas. Komposisi mineral penyusunnya adalah gelas vulkanik $<10 \%$, fragmen kristal (plagioklas dan kuarsa) 25$30 \%$.

Satuan ini ditemukan di bagian selatan hingga baratdaya daerah penelitian, yaitu pada daerah kampung Bangsaya, Nanggerang, Pameulahan hingga Legokeurteuw.

\subsection{Struktur Geologi}

Dari hasil interpretasi DEM dan M orfometri terlihat adanya struktur lingkaran yang diperkirakan adalah kaldera purba yang melingkar sepanjang G. Kutamanjangkar, G. Buled dan G. Puncaksalam dan selain itu terlihat juga adanya kelurusan yang umumnya berarah baratlaut-tenggara dan barat-timur (Gambar 8). Sesar berarah barat-timur dengan kemiringan tegak ditandai dengan kontak hornblenda andesit dengan piroklastik, kenampakan itu terlihat di sebelah Utara G. Buled (Sukandar, 2006).

Investigasi geologi struktural menunjukkan bahwa pengendalian utama alterasi dan mineralisasi pada batuan intrusif andesit dan dasit sebagai sumber mineral hidrotermal dan logam adalah sesar dekstral berarah timurbarat. Sesar normal berarah barat laut-tenggara merupakan koridor struktural sepanjang zona bukaan mineralisasi. U rat kuarsa didistribusikan di sepanjang zona dilasional. Kecenderungan umum urat kuarsa adalah $\mathrm{N}$ $143^{\circ}$ BT / $78^{\circ}$, relatif sejajar dengan zona bukaan mineralisasi (Wahyudiono, dkk., 2011).

\subsection{Alterasi dan Mineralisasi Gunungapi Purba Soreang}

Bagian fasies sentral Gunungapi purba Soreang menunjukan alterasi dan mineralisasi pada tubuh batuan induk porfiri dasit dan diorit. M ineralisasi yang penting berhubungan erat dengan adanya struktur kaldera. Hasil penelitian dari PT Pancaraksa Abadi (Sukandar, 2006) menyebutkan bahwa zona ubahan lempung pirit sepanjang Gunung Kutamanjangkar dan Cigadog yang terletak di dalam lingkaran kaldera tersebut dan di luarnya seperti di Pondokmerem dan Cikupa, di mana termasuk daerah anomali dengan 9-60 ppm dari hasil pendulangan (Gambar 9).

Proses alterasi dan mineralisasi hidrotermal ini menghasilkan mineral alterasi yang dapat dikelompokkan menjadi empat zona (Corbett \& Leach, 1996), yaitu zona silika, zona kloritkarbonat, zona illit-kaolinit, dan zona smektit. $M$ ineral-mineral asosiasi yang dijumpai berupa kuarsa, klorit, karbonat (kalsit dan dolomit) (Gambar 9b), illit (serisit), kaolinit, smektit, dickite, diaspor, opal, dan mineral sulfat (gipsum). Sedangkan mineral-mineral bijih yang muncul berupa pirit, galena, dan sfalerit.

Perbandingan antara karakteristik endapan hidrotermal di daerah penelitian dengan karakteristik ideal tipe endapan epitermal, memperlihatkan bahwa endapan hidrotermal di daerah penelitian lebih mencirikan kepada 


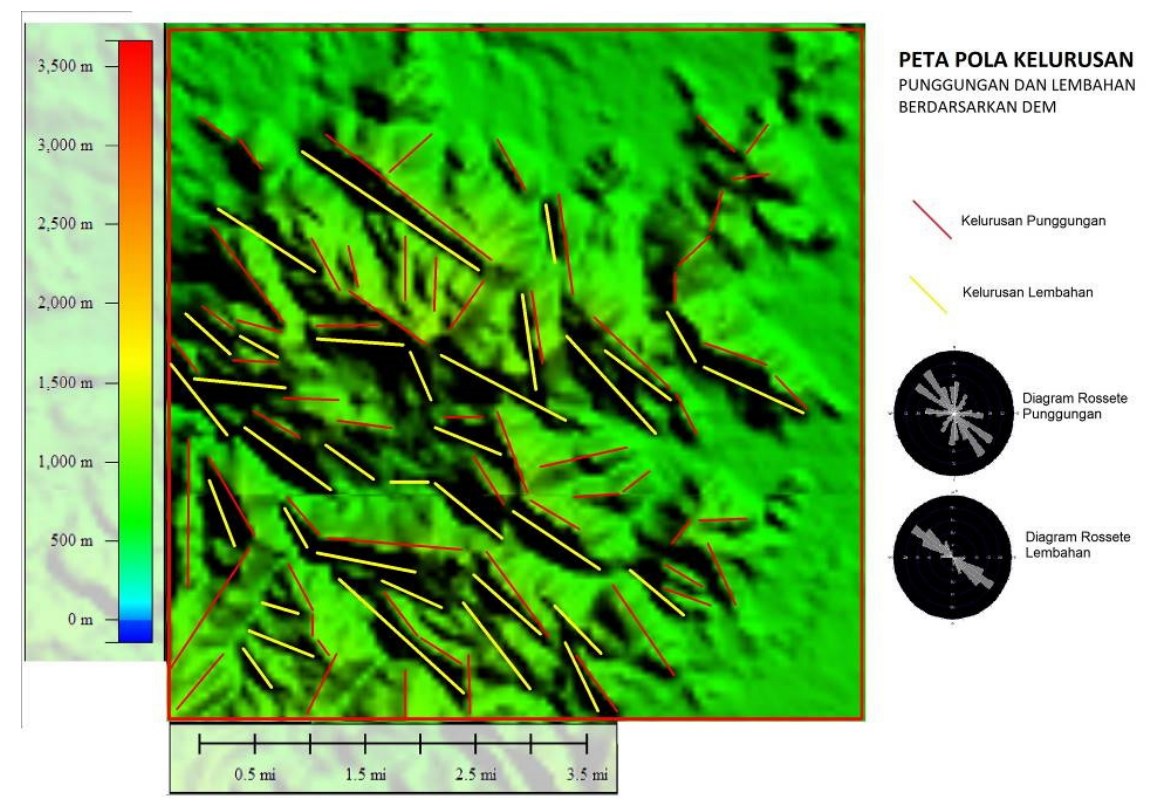

Gambar 8. Peta Pola Kelurusan Punggungan dan Lembahan Berdasarkan Digital Elevation M odel (DEM).

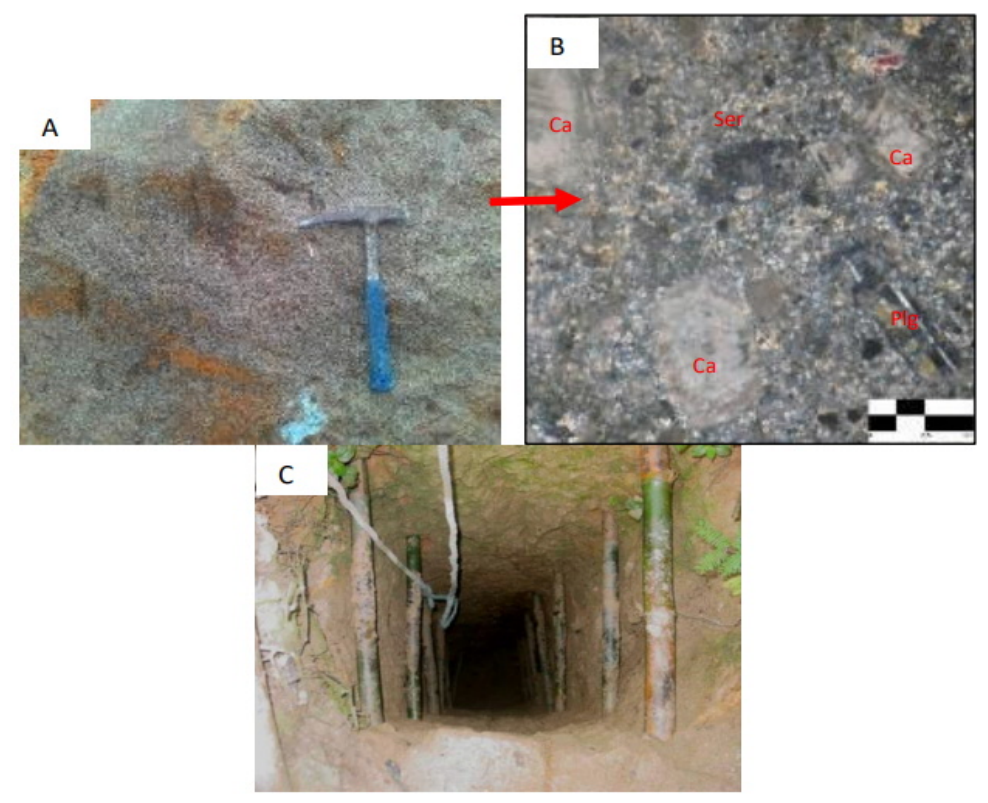

Gambar 9. (A) Foto singkapan porfiri andesit teralterasi dan (B) M ikrofotografi sayatan tipis andesit teralterasi. Plagiklas terubah menjadi karbonat sedangkan masa dasar berubah menjadi serisit ( $\mathrm{C} a=K$ arbonat; Plg=Plagioklas; Ser=Serisit). (C) Foto Lubang galian tambang masyarakat dengan kisaran dimensi $1 \times 1 \mathrm{~m}$ dengan kedalaman 10-30 meter.

tipe endapan epitermal sulfida rendah (low sulphidation) (Hedenquist \& Arribas, 2017; Sillitoe, 2015). Kawasan yang memiliki intensitas alterasi dan mineralisasi adalah pada intrusi dan kontak-kontak dengan gumuk vulkanik-piroklastik. Sebagai contoh, daerah Kutawaringin di bagian tengah daerah 
penelitian merupakan daerah dengan intensitas alterasi dan mineralisasi yang tinggi.

Di luar zona fasies pusat, ditemukan diorit teralterasi pada zona kaolit dan terdapat kemunculan pirit. Alterasi dan mineralisasi pada zona luar fasies pusat diduga merupakan kontrol dari struktur geologi (Carranza, 2009; Corbett, 2009) seperti kekar dan sesar yang berkembang pada fasies proksimal dan medial.

\section{KESIMPULAN}

a. Gununapi Purba Soreang merupakan gunungapi strato-vulkanik yang tidak aktif namun masih menunjukan sisa-sisa batuan gunungapi seperti intrusi, lava, dan piroklastik serta geomorfologi khas gunungapi seperti kubah/kerucut gunungapi dan perbukitan melingkar sisa kaldera.

b. Gunungapi Purba Soreang menunjukan fasies gunungapi pusat, proksimal, dan medial.

c. Potensi cebakan emas yang dimanifestasikan dengan persebaran intensitas batuan teralterasi dan termineralisasi pada Gunungapi Purba Soreang berada pada fasies pusat.

d. Eksplorasi cebakan emas dapat difokuskan pada zona fasies pusat gunungapi. Namun, pengembangan eksplorasi lanjutan juga harus mempertimbangkan aspek kontrol struktur geologi yang mungkin membawa mineralisasi keluar zona fasies pusat.

\section{UCAPAN TERIMA KASIH}

Penulis mengucapkan terima kasih kepada Laboratorium Petrologi dan Mineralogi, Fakultas Teknik Geologi, Universitas Padjadjaran yang telah memberikan fasilitas dalam preparasi dan pengamatan petrografi sebagai data pendukung dalam penelitian ini.

\section{DAFTAR PUSTAKA}

Alzwar, M., Akbar, N., \& Bachri, S. (1992). Peta Geologi Lembar Garut dan Pameungpeuk, Jawa, skala 1: 100.000. Puslitbang Geologi, Bandung.
Bronto, S. (2003). Penelitian Sumber Daya Energi dan Mineral Berbasis IImu Gunung api. M ajalah M ineral \& Energi, 1, 24-26.

Bronto, S. (2006). Fasies gunung api dan aplikasinya. Indonesian Journal on Geoscience, 1(2), 59- 71.

Bronto, S., Achnan, K., \& Utoyo, H. (2004). Penemuan Sumber Baru M ineralisasi di Daerah Cupunagara, Kecamatan Cisalak, Kabupaten Subang-Jawa Barat. The 33rd Convention \& Exhibition.

Bronto, S., Budiadi, E., \& Hartono, H. G. (2006). A new perspective of Java Cenozoic volcanic arcs.

Bronto, S., \& Hartono, U. (2003). Strategi penelitian emas berdasarkan konsep pusat Gunung Api. Prosid Ing Kolokium Energi Dan Sumber Daya Mineral, 172-189.

Bronto, S., \& Hartono, U. (2006). Potensi sumber daya geologi di daerah Cekungan Bandung dan sekitarnya. Indonesian Journal on Geoscience, 1(1), 9- 18.

Carranza, E. J. M. (2009). Controls on mineral deposit occurrence inferred from analysis of their spatial pattern and spatial association with geological features. Ore Geology Reviews, 35(34), 383- 400.

Charlton, R. (2007). Fundamentals of fluvial geomorphology. Routledge.

Corbett, G. (2009). A natomy of porphyry-related $\mathrm{Au}-\mathrm{Cu}-\mathrm{Ag}-\mathrm{Mo}$ mineralised systems: Some exploration implications. Australian Institute of Geoscientists North Queensland Exploration Conference, 1- 13.

Corbett, G. J., \& Leach, T. M. (1996). Southwest Pacific Rim Gold Copper Systems. Structure, Alteration and Mineralization, Manual for an Exploration W orkshop, Jakarta.

Fryirs, K. A., \& Brierley, G. J. (2012). Geomorphic analysis of river systems: an approach to reading the landscape. John W iley \& Sons.

Grosse, P., de Vries, B. van W., Euillades, P. A., Kervyn, M., \& Petrinovic, I. A. (2012). Systematic morphometric characterization of volcanic edifices using digital elevation models. Geomorphology, 136(1), 114-131.

Hedenquist, J. W., \& Arribas, R. A. (2017). Epithermal ore deposits: first-order features relevant to exploration and assessment. Mineral Resources to Discover, 1, 47-50. 
Huggett, R. (2007). Fundamentals of geomorphology. Routledge.

M artodjojo, S. (2003). The evolution of Bogor, W est Java basin. ITB Bandung Publishing Bandung.

Ngkoimani, L. O. (2005). Magnetization of andesites rocks of Java and their implication to the paleomagnetization and tectonic evolution; abstract. Kumpulan A bstrak Disertasi S, 3.

Prima, O. D. A., \& Yoshida, T. (2010). Characterization of volcanic geomorphology and geology by slope and topographic openness. Geomorphology, 118(1-2), 22-32.

Silitonga, P. H. (1973). Peta Geologi Lembar Bandung, Djawa. Direktorat Geologii.

Sillitoe, R. H. (2015). Epithermal paleosurfaces. Mineralium Deposita, 50(7), 767- 793.

Sudjatmiko. (1972). Peta Geologi Lembar Cianjur, skala 1: 100.000 . Pusat Penelitian dan Pengembangan Geologi.
Sukandar, H. (2006). Laporan Eksplorasi Emas Kutawaringin. Bandung.

Sunardi, E., \& Koesoemadinata, R. P. (1999). New K-Ar Ages and The M agmatic Evolution of The Sunda-Tangkuban Perahu Volcano Complex Formations, W est Java, Indonesia. Proceedings of the 28th Annual Convention, IAGI, Jakarta, $\mathrm{H}, 63-71$.

Van Bemmelen, R. W. (1949). General Geology of Indonesia and adjacent archipelagoes. The Geology of Indonesia.

Van Zuidam, R. A. (1977). Terrain classification using SLAR imagery- A geomorphological approach. ITC Journal, (4), 705-716.

Wahyudiono, J., Abdullah, C. I., \& Abidin, H. Z. (2011). Kontrol Sesar Terhadap Pola Sebaran Urat Kuarsa dan Mineralisasi Emas Daerah Kutawaringin, Jawa Barat. Jurnal Geologi Dan Sumberdaya M ineral, 21(3), 163-175. 